OPEN ACCESS

Edited by:

Tasos Hovardas,

University of Cyprus, Cyprus

Reviewed by:

Lily M. van Eeden,

University of Sydney, Australia Aaron Wirsing, University of Washington Tacoma,

United States

*Correspondence:

Andrea T. Morehouse amorehouse@winiskresearch.com

Specialty section

This article was submitted to

Conservation,

a section of the journal Frontiers in Ecology and Evolution

Received: 29 August 2019 Accepted: 06 January 2020

Published: 03 February 2020

Citation:

Morehouse AT, Hughes C, Manners N, Bectell J and Bruder T (2020) Carnivores and Communities: A Case Study of Human-Carnivore Conflict Mitigation in Southwestern

Alberta. Front. Ecol. Evol. 8:2. doi: 10.3389/fevo.2020.00002

\section{Carnivores and Communities: A Case Study of Human-Carnivore Conflict Mitigation in Southwestern Alberta}

\author{
Andrea T. Morehouse ${ }^{1,2 *}$, Courtney Hughes ${ }^{3}$, Nora Manners ${ }^{1}$, Jeff Bectell ${ }^{1}$ and \\ Tony Bruder ${ }^{1}$ \\ ${ }^{1}$ Waterton Biosphere Reserve, Pincher Creek, AB, Canada, ${ }^{2}$ Winisk Research and Consulting, Bellevue, AB, Canada, \\ ${ }^{3}$ Alberta Environment and Parks, Government of Alberta, Peace River, AB, Canada
}

Facilitating long-term coexistence between people and large carnivores is a persistent, global conservation challenge. Evidence-based decisions to help design and implement programs that promote coexistence between people and carnivores are required. Using a case study approach, we evaluated the effectiveness of conflict mitigation efforts of a community-based program in southwestern Alberta, Canada: the Waterton Biosphere Reserve's (WBR) Carnivores and Communities Program (CACP). The CACP's overall goal is to support coexistence of people and large carnivores through initiatives including reducing livestock loss, damage to stored crops, and safety risks from carnivores by engaging residents in hands-on programming. We used an online survey to assess program participants' general awareness of and motivation to engage in the CACP, safety risks associated with living with large carnivores, and attractant management and deadstock removal programming. We received 116 completed surveys. Survey results indicated that participants felt the CACP effectively reduced conflicts with large carnivores, increased their sense of safety when living with large carnivores, and enabled them to learn skills and gain confidence in using mitigation tools (e.g., bear spray). We also evaluated temporal trends in large carnivore conflicts using occurrence records (i.e., complaint data) from 1999 through 2016. We classified these data into incidents (e.g., situations where carnivores caused property damage, obtained anthropogenic food, killed or attempted to kill livestock or pets) and focussed on incidents related to attractants, including deadstock. We focus our incident review on grizzly bears because most agricultural attractant incidents in the study area are caused by grizzly bears. We used a Chow test to evaluate if the 2009 CACP commencement represented a break point or structural change in the data. Although total reported incidents increased from 1999 through 2016, we show both reported attractant and deadstock-based incidents changed from increasing to decreasing after the CACP implementation in 2009. Our results demonstrate the effectiveness of a contextually specific, community-based approach to addressing human-carnivore conflicts. More broadly, our evaluation and lessons learned provide other conservation organizations with a useful framework for addressing human-carnivore or other wildlife conflicts.

Keywords: coexistence, community-based conservation, human-wildlife conflict, large carnivores, occurrence data, program evaluation, survey 


\section{INTRODUCTION}

Achieving coexistence between humans and large carnivores is a pressing challenge to global conservation efforts and those tasked with managing human-carnivore conflicts (Decker and Chase, 1997; Ripple et al., 2014). Indeed, as Peterson et al. (2010) suggest, portrayals of carnivores as conscious adversaries or rivals to human interest can be problematic for conservation efforts. The different values people hold and perspectives on what it means to share the landscape with large carnivores, combined with possible threats to human life and economic interests can exacerbate this challenge (Wang and Macdonal, 2006; Holmern et al., 2007; Dickman et al., 2011).

Human-carnivore conflicts can manifest in many ways, including damaging standing and stored crops (e.g., Pérez and Pacheco, 2006; Hoare, 2012), killing livestock or pets (e.g., Naughton-Treves et al., 2003; Miller et al., 2015), destroying property (e.g., Wilson et al., 2006; Treves, 2009), and threatening human safety (e.g., Treves and Naughton-Treves, 1999; Ratnayeke et al., 2014). Additionally, large carnivores can infringe on an individual's land use, livelihood and well-being (Young et al., 2015; Miller et al., 2016; Hughes and Nielsen, 2018). As a result, support for conservation efforts can diminish locally (Anand and Radhakrishna, 2017), with carnivores being relocated (Blanchard and Knight, 1995; Linnell et al., 1997; Milligan et al., 2018) or killed (Treves et al., 2016). Further, population declines for many species can be linked to persistent conflict (Nyhus, 2016). On the other hand, large carnivore species are also valued for their ecological role or existence value (Kellert, 1980; Bruskotter et al., 2015; Vucetich et al., 2015; Dorresteijn et al., 2016), and are often used as flagship species in conservation efforts (Macdonald et al., 2017). Recent research suggests that for some species, such as brown bears (Ursus arctos) in Europe and Japan as well as gray wolves (Canis lupus) in the United States, populations have rebounded across multi-use landscapes in part due to shifts in human attitudes and proclivity to adopt conservation efforts (Chapron et al., 2014; Mech, 2017; Sato, 2017).

Despite some examples of successful coexistence, support for conserving carnivores is not uniform and can vary between groups of people, including rural land owners and urban residents, particularly when rural people might directly interact with these animals (Kellert et al., 1996; Bjerke and Kaltenborn, 1999; Ericsson et al., 2004; Karlsson and Sjöström, 2007; Hughes and Nielsen, 2018). In a rural context, tolerance for large carnivores may be contingent on reducing the safety risks or economic impacts on human livelihoods these species can cause (Riley and Decker, 2000; Ericsson et al., 2008; Knopff et al., 2016; Hughes and Nielsen, 2018). Further, rural communities and agricultural areas typically bear the costs of living with carnivores (Newsome et al., 2015; Morehouse and Boyce, 2017; Hughes and Nielsen, 2018). Although problems and solutions to humanwildlife conflict tend to be context-specific (Morehouse and Boyce, 2017), the general premise of these conflicts is consistent: where people and wildlife share the landscape, challenges arise. There is no shortage of literature documenting human-wildlife conflicts and mitigation efforts across myriad landscapes (e.g.,
Kaczensky, 1999; Musiani et al., 2003; Gunther et al., 2004; Shivik, 2006; Inskip and Zimmermann, 2009), but examples of program evaluation are still lacking (Eklund et al., 2018).

We used a case study approach (Espinosa and Jacobson, 2012; Harrison et al., 2017; Johnson et al., 2018; Proctor et al., 2018) combining carnivore incident report data and social attitudes to examine a community-based human-carnivore conflict mitigation program in southwestern Alberta, Canada: the Waterton Biosphere Reserve's (WBR) Carnivores and Communities Program (CACP). This program focusses on decreasing conflicts between large carnivores and people in an agricultural landscape by supporting the community through collaborative projects, capacity building, and educational outreach. The CACP also provides an avenue for the expression of community concerns. We conceptually modeled the program's main activities using a Theory of Change $(\mathrm{ToC})$ model to identify the processes and anticipated results of the program (Margoluis et al., 2009; Center for Theory of Change, 2013; Woodhouse et al., 2015; Biggs et al., 2016; Allen et al., 2017; Balfour et al., 2019). Theory of Change conceptually lays out a program's logical and causal linkages that lead to a desired outcome, and has been used in conservation to assess achievement of objectives in illegal wildlife trade (Biggs et al., 2016), species-level conservation impacts (Washington et al., 2015), organizational performance (McKinnon et al., 2015), policy direction and management action (Balfour et al., 2019), and environmental education for protected areas (Zorrilla-Pujana and Rossi, 2016). Our case study provides an example of a community-based program evaluation, helps articulate what efforts are working at a local level to facilitate human-carnivore coexistence, and offers insights to help guide future program direction both locally and to other developing coexistence efforts more broadly.

\section{Southwestern Alberta and Waterton Biosphere Reserve's Carnivores and Communities Program}

Provincially, southwestern Alberta has a high level of carnivoreagricultural conflicts (Morehouse and Boyce, 2017; Morehouse et al., 2018). People and large carnivores occupy the same landscape, and private agricultural lands used for livestock and crop production abut forested, mountainous public lands. Four native large carnivore species are present, including cougars (Puma concolor), black bears (U. americanus), wolves (C. lupus), and grizzly bears (U. arctos), and their home ranges substantially overlap private agricultural lands (Morehouse and Boyce, 2016; Loosen et al., 2018; Bassing et al., 2019). These large carnivore species are considered secure (i.e., not at risk) within Alberta except for grizzly bears, which have been listed as provincially threatened since 2010 (Alberta Government, 1991, 2012, 2016; Alberta Environment Parks, 2016; Government of Alberta, 2017).

The CACP works with southwestern Alberta communities to advance its goal of supporting coexistence of people and large carnivores. An increase in grizzly bear sightings in the early 2000s coupled with growing community frustration over human-carnivore conflicts and provincial government wildlife management decisions precipitated the CACP establishment. 
In 2009, local community members along with government and non-government organizations came together as the CACP to develop locally relevant solutions to address carnivoreagricultural conflicts. In 2011, the Carnivore Working Group (CWG) was established to provide direction and guidance to the CACP. The group meets at least three times per year, is guided by a terms of reference (www.watertonbiosphere.com), and uses consensus-based decision-making.

The CACP has three main activities including attractant management, deadstock (i.e., livestock carcass) removal, and bear safety workshops (Supplementary Material S1). Previous research has indicated agricultural products and practices, including livestock, silage, grain/feed (hereafter referred to as crops), and deadstock are major attractants for carnivore species, particularly grizzly bears (Morehouse and Boyce, 2011, 2017; Northrup and Boyce, 2012). Attractant management refers to restricting carnivore access to food items by using tools such as electric fencing, bear-resistant grain bin doors, and upgraded grain storage (e.g., metal shipping containers, hopperbottom bins) (Supplementary Material S1). Deadstock removal refers to direct services provided to ranchers whereby livestock carcasses are picked up and completely removed from a property (Supplementary Material S1). Bear safety workshops provide information to ranchers and rural residents on bear and other carnivore behavior, human safety precautions to take in carnivore country, and the proper use of bear spray. The CACP also routinely disseminates information on human-carnivore conflict mitigation, livestock depredation compensation, and sciencebased wildlife management through their website, face-to-face community meetings, tours of CACP projects, youth outreach events, local newspapers, e-mail newsletters, and social media posts as part of their educational outreach. The CACP uses only non-lethal methods in their programming. However, in Alberta, landowners have the legal right to kill a wolf, cougar, or black bear on their property (Alberta Government, 2019). Grizzly bears are protected, and landowners must rely on the provincial government to remove and/or relocate a problem bear (Alberta Environment Parks, 2016).

While anecdotal evidence suggests the CACP is well-received by individuals within the target communities and is considered to support provincial wildlife management objectives of reducing carnivore mortality and relocation, a formal program evaluation has not been completed. We evaluated the three aforementioned CACP activities using a ToC model (Figure 1) to collect survey data on participants' perspectives of the CACP's effectiveness relative to reducing economic costs and human safety risks and an analysis of carnivore conflict data.

\section{STUDY AREA}

Our study area is in southwestern Alberta, Canada. The CACP operates in an area $\left(\sim 5,012 \mathrm{~km}^{2}\right)$ that extends roughly from Chain Lakes Provincial Park in the north, British Columbia to the west, Montana, USA to the south, and an approximation of grizzly bear range to the east (Figure 2). The area includes four local municipal districts: Ranchland, Pincher Creek, Willow
Creek, and Cardston County. The CACP operates predominately on private lands used for livestock and crop production (Statistics Canada, 2016).

\section{METHODS}

We used two methods to evaluate the CACP's activities: (1) an online purposive survey of local ranchers and other rural residents across target communities within the program area, and (2) a review of large carnivore incident records. We focused on rancher and rural residents' perspectives and experiences as they were the target audience and participated in the CACP's activities. We also summarize yearly costs for the CACP.

\section{Social Survey}

We used an online survey as a cost-effective and efficient data collection technique to evaluate the effectiveness of the CACP directly from the program participants' perspectives and experiences (Archer, 2003; Waylen et al., 2010; Salerno et al., 2016). The survey was constructed in Survey Monkey (2018) and organized into the following sections: demographics, general awareness and motivation to participate, safety risks and sense of security associated with large carnivores, assessment of attractant management and deadstock removal programming, and communications and future direction (Supplementary Material S2).

The survey was emailed directly to CACP participants and community members using the programs' electronic mailing list $(N=504)$ and partnering municipal government email lists $(N=$ 145) for deadstock pickup. The survey was also available in print format for those without internet access or if individuals had a preference to use a paper version. To increase participation, we advertised the survey in three different local newspapers, placed posters at key public locations, and shared on the WBR website and social media (Facebook). We also emailed two reminders to complete the survey. The survey was open for 7 weeks.

We recognize the limitations with this sampling technique, including selection and social desirability bias (Palinkas et al., 2015). However, as this is a case study to assess the situated knowledge and experience of individuals familiar with the CACP, and given the length of time the survey remained open, repeated completion reminders, and costs and time associated with using probabilistic survey techniques, we believe our approach was effective at soliciting the data required for our evaluative purposes (Dillman et al., 2009; Barratt and Lenton, 2010; Palinkas et al., 2015). Additionally, we followed several of the suggestions in Woodhouse et al. (2015) for evaluating conservation programs, thereby further supporting the appropriateness of our methods.

\section{Occurrence Records}

We used southwestern Alberta occurrence records (i.e., complaint data) from 1999 to 2016 to evaluate temporal trends in large carnivore incident type. In Alberta, when an individual has an interaction with a large carnivore, they can report it to the Fish and Wildlife division of the provincial government. The details of that event are recorded as a text summary in a provincial occurrence record database, and these reports are referred to 


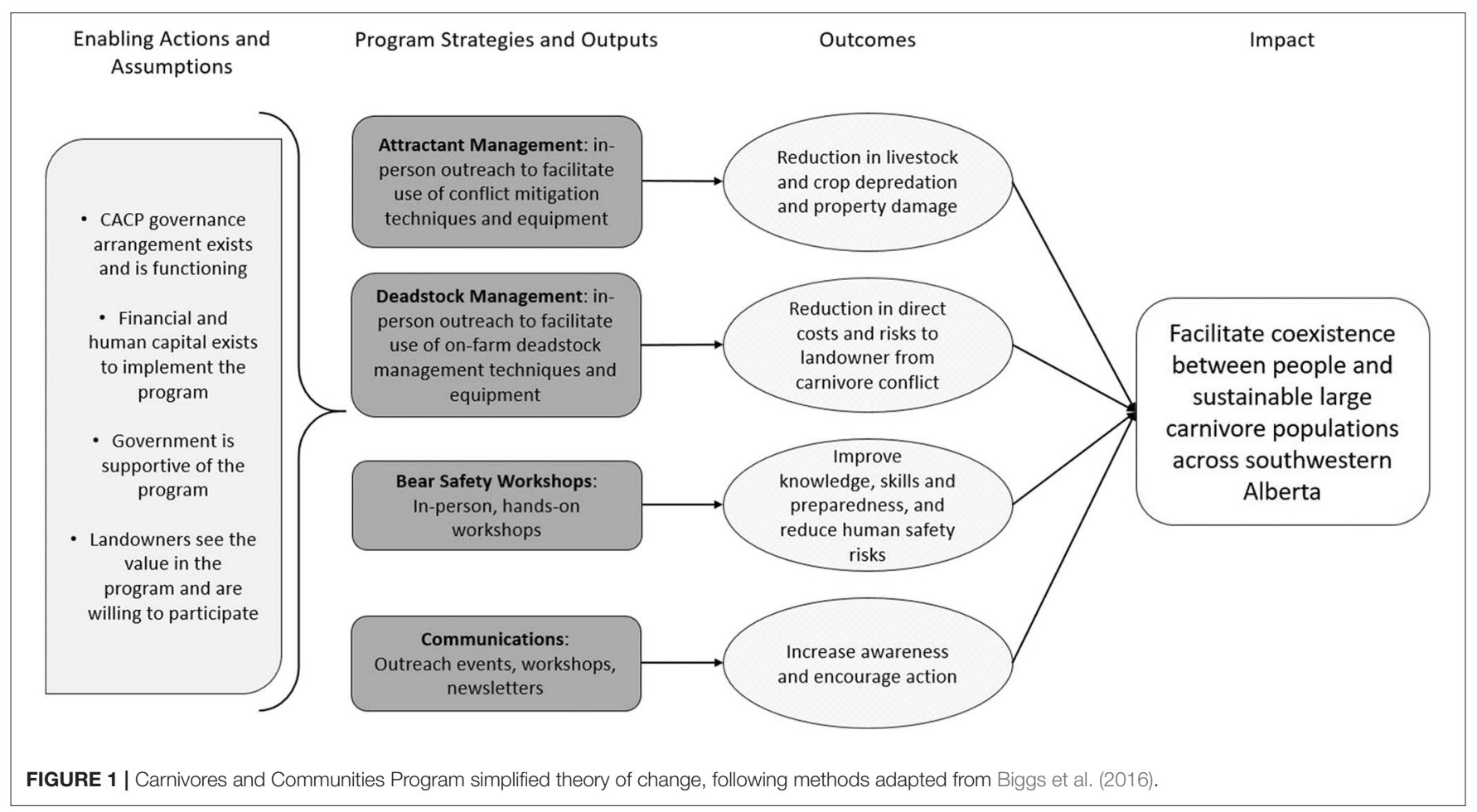

as occurrence records. We reviewed occurrence records from 1999 to 2016 from the Cardston, Pincher Creek, Blairmore, and Claresholm Fish and Wildlife Districts to identify large carnivore incidents (Malish and Loosen, 2017a,b; Morehouse and Boyce, 2017). We define an incident as a situation where the large carnivore caused property damage, obtained anthropogenic food, killed or attempted to kill livestock or pets, or was involved in a vehicle collision (Hopkins et al., 2010; Morehouse and Boyce, 2017). We excluded all non-incident occurrence records (e.g., sightings). We focus on incidents because they represent actual reported interactions between people and large carnivores, and the conflict mitigation efforts of the CACP have focussed on reducing various types of incidents. Following the methods of Morehouse and Boyce (2017), we further classified each incident as involving property damage, livestock (depredation or injury), attractants, or other (primarily vehicle collisions). Attractant types used in our analysis included deadstock (i.e., boneyards), grain, vegetation, bee yard, silage, pet food, garbage, bird feeder, or other (e.g., chicken feed, wildlife hides).

Because we were interested in evaluating temporal patterns in relation to the CACP, we focussed on incidents that were related to two of the three primary $\mathrm{CACP}$ initiatives: the deadstock removal program and attractant management projects. For incidents involving deadstock, we used data from all four large carnivore species because all four species have been observed scavenging from boneyards (Morehouse and Boyce, 2011; Banfield, 2012; Northrup and Boyce, 2012). First, we summarized the number of deadstock incidents over time. We then used a Chow test (Chow, 1960) to evaluate if the 2009 commencement of the CACP represented a break point or structural change in the data. In time series data, the Chow test can be used to evaluate if a known a priori point in the series (e.g., the start of the CACP) effectively splits the data into two parts. The Chow test evaluates if the two sets of observations before vs. after the assumed break point can be represented by the same regression line or if two separate regression lines provide a better fit (Chow, 1960). Thus, we used a Chow test to determine if the trend in deadstock incidents differed before vs. after the implementation of the CACP. We present regression values for these trends.

Next, we focussed on incident patterns for grizzly bears evaluating both attractant and livestock related incidents. We focussed on grizzly bears because most agricultural attractant incidents in the study area are caused by grizzly bears (Morehouse and Boyce, 2017), and all CACP attractant management projects have been designed predominantly to mitigate bear-agricultural conflicts. We evaluated changes in grizzly bear attractant and livestock related incidents independently, and again used a Chow test to evaluate if the 2009 CACP implementation represented a structural change in the data. We present regression values for these trends.

We restricted our analysis to include only incident records that fell within the CACP focal area. We defined our study area as a $2.4 \mathrm{~km}$ buffer around the CACP's deadstock pickup zone. The deadstock zone was originally developed to encompass the area of southwestern Alberta with the highest number of large carnivore incidents. We used the deadstock pickup zone as our study area because the CACP generally does not remove deadstock outside of this zone and attractant management work has focussed on sites within this same area (though for both 


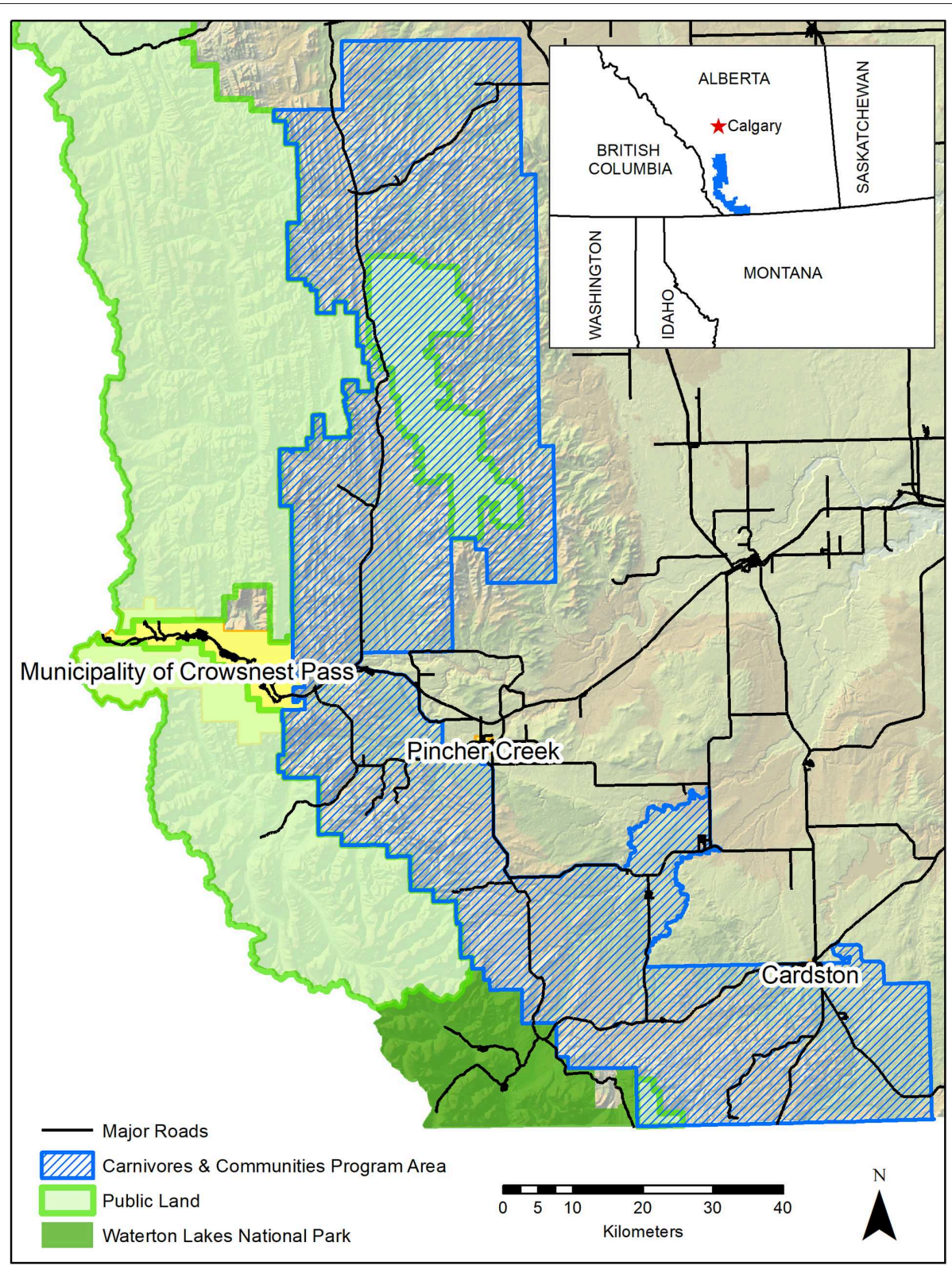

FIGURE 2 | The Waterton Biosphere Reserve's Carnivores and Communities Program area in southwestern Alberta. Pictured are the towns of Pincher Creek, Cardston, and the Municipality of Crowsnest Pass.

programs specific sites outside this zone are evaluated on a case by case basis). Because we believe the impact of the CACP potentially extends beyond the boundaries of the deadstock zone, we buffered the area by $2.4 \mathrm{~km}$ as this represents the average daily linear movement by grizzly bears within the larger ecosystem (Apps et al., 2006). We acknowledge that incidents do occur outside of the buffered area, but our interest was in evaluating the program's impact within the CACP focal area rather than evaluating the spatial extent of the CACP impact. Thus, the incidents outside the focal area are beyond the scope of our analysis and their exclusion should not impact our results.

\section{Program Costs}

We summarized the annual costs in Canadian dollars (CAD) of the main components of the CACP from the 2012-13 through 2018-19 fiscal years (April 1 to March 31). We excluded earlier years (i.e., 2009-2011) when the program was still in formative stages because costs in these early years did not accurately reflect the resources required for the fully functional CACP. We included a summary of the annual costs for attractant management, deadstock removal, education, and outreach (including bear safety workshops), and personnel, in order to provide an overview of the financial commitment required to operate the CACP. We did not include in-kind 
and matching contributions because those costs are not tracked. Thus, the costs presented represent only the money paid by the WBR as charged to the organization's operating grants.

\section{RESULTS}

From 2009 to 2018, the CACP completed 70 attractant management projects, removed $\sim 4,300$ livestock carcasses from the landscape, and hosted 8 bear safety workshops.

\section{Social Survey}

On average, the survey took $35 \mathrm{~min}$ to complete per respondent, with 116 completed surveys used in our analysis out of 174 returned. We included only those responses from individuals within our study area or those that had indicated they had participated in at least one of the three programs. This resulted in excluding two surveys where respondents declined participation, 55 incomplete surveys (e.g., agreement to participate but no other response or only demographics provided), and one completed survey where the respondent lived $\sim 200 \mathrm{~km}$ outside our study area.

Respondents included ranchers who owned and raised livestock (primarily cattle but also sheep and goats) or crops, rural residents who owed land or hobby farms (e.g., small number of chickens), and urban residents that lived in larger, but still rural, population centers (Table 1). Ages ranged from 25 to over 75 years old with 65 to 74 years old as the most common age bracket. Of all respondents, $87.9 \%$ indicated a general awareness of the CACP, with greatest awareness for deadstock removal services and bear safety training (Table 2). However, $19.8 \%$ of all respondents indicated they had not directly participated in any CACP activities. Of those that responded $(n=83), 73.5 \%$ indicated overall satisfied with the CACP and $65.5 \%$ felt wellinformed on program activities and outcomes.

When respondents $(n=116)$ were asked which initiatives they had participated in, $56.9 \%$ attended community meetings or tours and $43.1 \%$ attended bear safety workshops. More ranchers and rural residents participated in deadstock programming (58.6\%) compared to attractant management projects (12.9\%). Top motivating factors to participate in the CACP included personal interest $(70.7 \%)$ and learning techniques to address ongoing carnivore conflicts (50.0\%). Specifically, ranchers and rural residents indicated learning how to reduce personal costs associated with carnivore coexistence (36.2\%) and ease of accessing programming (29.3\%) as top reasons for participating.

TABLE 1 | Demographics of survey respondents.

\begin{tabular}{lccc}
\hline & Female & Male & Total \\
\hline Rancher & 21 & 51 & 72 \\
Rural resident & 19 & 19 & 38 \\
Urban resident & 4 & 2 & 6 \\
Total & 45 & 72 & 116
\end{tabular}

\section{Bear Safety Workshops}

Respondents' level of large carnivore safety concerns varied by species (Table 3). Respondents felt safest around wolves and the least safe around grizzly bears (Table 3 ). Several respondents indicated they had a personal experience with grizzly bears $(50.0 \%)$ or black bears $(44.8 \%)$ in which there was a safety risk to themselves or family (Table S1). Indeed, most (56.0\%) respondents identified personal/family safety as their greatest concern associated with living with large carnivores (Table S2). In contrast, only $8.6 \%$ of respondents experienced a personal/family safety risk from wolves. Pet safety was also a concern, particularly with cougars (Table S1).

Of those that had experienced safety concerns, $30.9 \%$ indicated they always reported their concerns to government officials (Table S3). However, 33.0\% indicated they never reported their safety concerns, with (15.5\%) citing a negative past experience with officials when reporting. Comments also reflected concerns that Fish and Wildlife officers were understaffed and experienced other job constraints, making timely response difficult, as indicated by one rancher: "While local officials try hard to deal with our concerns, they are often limited by time, resources and jurisdiction. Often we do call at least to notify them of a problem, though in some cases we are able to deal with it ourselves." Of respondents that did report, the two most important reasons included ensuring officials documented the information to guide future management decisions (48.3\%), and ensuring officials were aware of problems (32.8\%).

In general, respondents held positive views of the bear safety workshops, with $<10 \%$ disagreeing with statements of

TABLE 2 | Survey respondents' level of awareness for various components of the Carnivores and Communities Program $(n=116)$

\begin{tabular}{lccc}
\hline & $\begin{array}{c}\text { Aware } \\
\text { (\%) }\end{array}$ & $\begin{array}{c}\text { Unsure } \\
\mathbf{( \% )}\end{array}$ & $\begin{array}{c}\text { Unaware } \\
\text { (\%) }\end{array}$ \\
\hline $\begin{array}{l}\text { General information about the } \\
\text { Carnivores and Communities } \\
\text { Program }\end{array}$ & 87.9 & 4.3 & 8.5 \\
$\begin{array}{l}\text { Deadstock removal program } \\
\text { Availability of financial supports }\end{array}$ & 92.2 & 1.7 & 6.0 \\
$\begin{array}{l}\text { for electric fencing } \\
\begin{array}{l}\text { Cost-sharing opportunities to } \\
\text { improve grain/feed storage }\end{array}\end{array}$ & 52.6 & 7.8 & 39.7 \\
\begin{tabular}{l} 
Bear Safety Training \\
\hline
\end{tabular} & 89.5 & 9.5 & 31.0 \\
\hline
\end{tabular}

TABLE 3 | Level of safety respondents indicated feeling for each large carnivore species. Results are expressed as percent responding.

\begin{tabular}{lcccc}
\hline & \multicolumn{4}{c}{ Percent (\%) } \\
\cline { 2 - 5 } & Safe & A little unsafe & Very unsafe & Unsure \\
\hline Grizzly bear $(n=116)$ & 18.1 & 52.6 & 27.6 & 1.7 \\
Black Bear $(n=114)$ & 41.2 & 51.8 & 6.1 & 0.9 \\
Wolf $(n=116)$ & 56.9 & 34.5 & 5.2 & 3.4 \\
Cougar $(n=115)$ & 28.7 & 57.4 & 10.4 & 3.5
\end{tabular}


effectiveness (Table 4). One rural resident commented that "the bear awareness course is a fantastic program and I encourage everyone I know that spends time on the land to take it." Of those that participated, $49.5 \%$ felt an increased sense of safety, and $61.6 \%$ stated they now carried bear spray as a result of training.

\section{Attractant Management and Deadstock Removal}

Sixty-three respondents identified having livestock and/or crops and were asked a series of questions about carnivore depredation or damage. All other respondents without livestock were directed to the next section on communications and future directions. Most respondents believed large carnivore depredation of livestock had increased over the past 5 years, particularly by grizzly bears (Table 5). Several indicated they had personally experienced livestock depredation or livestock stress from grizzly bears $(44.8 \%)$, wolves $(35.3 \%)$, cougars $(27.6 \%)$, or black bears (18.1\%, Table S1). This was one of their primary concerns associated with living with large carnivores (Table S2). Responses were more evenly split when asked about trends in crop damage, with $34.6 \%$ indicating they perceived increased damage or loss due to grizzly bears while $28.8 \%$ said it had decreased (Table 5). Of those that had experienced livestock depredation, $71.2 \%$ indicated they reported the incidents to government officials at least half the time (Table S3). Conversely, only $37.2 \%$ of respondents reported stored grain or feed damage at least half the time (Table S3).

Most respondents regarded the deadstock removal program positively (Table 4). Notably, $75.5 \%$ said the program helped reduce conflict with large carnivores, and $84.6 \%$ indicated they wanted the program to continue. Regardless of whether or not they had participated in the deadstock removal program $(n=83)$ $77.1 \%$ perceived the program was effective at reducing conflicts.
A rancher indicated that "it is an integral part of attractant management and is directly beneficial to a large number of people."

Respondents were often undecided in their views on the effectiveness of the attractant management program (Table 4). Of those that participated $(n=51), 45.1 \%$ agreed the program helped reduce conflicts with carnivores. However, one rancher noted there needed to be more consistency in application, with "all the producers on side. Right now it is piecemeal and large carnivores travel to the easiest target. [The] program needs area consistency to have large benefits." Regardless, $67.9 \%$ perceived the program to be overall effective at reducing conflicts.

\section{Occurrence Records}

We reviewed 6,621 occurrence records from 1999 to 2016 that had spatial locations associated with them. Of those, we extracted 1,696 incident records that fell within our study area (remaining occurrences were outside are study area or non-incidents). Total combined incidents for the four large carnivore species increased from 1999 through $2016\left(y=5.67 \mathrm{x}+40.40, R^{2}=0.53, p\right.$ $<0.001$, Figure 3). However, incidents related to deadstock changed from significantly increasing to significantly decreasing after the implementation of the CACP in $2009(F=8.40, p=$ 0.004 ; Pre-CACP $y=0.99 \mathrm{x}+2.27, R^{2}=0.56, p=0.01$; PostCACP $y=-2.16 \mathrm{x}+21.82, R^{2}=0.51, p=0.05$; Figure 4). For grizzly bears, total incidents generally increased from 1999 through 2016, though 2015 and 2016 incidents were lower $(\mathrm{y}=$ $4.45 \mathrm{x}-2.01, R^{2}=0.70, p<0.001$, Figure 5). Trends in grizzly bear attractant incidents changed from a significant increase to a non-statistically significant decrease after the 2009 start of the CACP $\left(F=6.28, p=0.01\right.$; Pre-CACP $y=1.16 \mathrm{x}+6.2, R^{2}=0.52$, $p=0.02$; Post-CACP $y=-3.05 \mathrm{x}+43.21, R^{2}=0.30, p=0.16$; Figure 5). The trend in grizzly bear livestock incidents, however,

TABLE 4 | Survey respondents' level of agreement on the effectiveness of the Waterton Biosphere Reserve's Carnivores and Communities Program bear safety training, attractant management, and deadstock removal initiatives.

\begin{tabular}{|c|c|c|c|c|c|c|c|c|c|}
\hline & \multicolumn{9}{|c|}{ Percent (\%) } \\
\hline & \multicolumn{3}{|c|}{$\begin{array}{l}\text { Bear Safety Workshop } \\
\qquad(n=99)\end{array}$} & \multicolumn{3}{|c|}{$\begin{array}{l}\text { Attractant Management } \\
\qquad(n=51)\end{array}$} & \multicolumn{3}{|c|}{$\begin{array}{l}\text { Deadstock Removal } \\
\qquad(n=53)\end{array}$} \\
\hline & Agree & Undecided & Disagree & Agree & Undecided & Disagree & Agree & Undecided & Disagree \\
\hline The program is readily available to landowners & 60.6 & 36.3 & 3.0 & 41.2 & 49.0 & 9.8 & 71.7 & 17.0 & 11.3 \\
\hline $\begin{array}{l}\text { The program helps reduce conflict with } \\
\text { carnivore species }\end{array}$ & $51.0^{a}$ & $41.8^{a}$ & $7.1^{\mathrm{a}}$ & 45.1 & 49.0 & 5.9 & 75.5 & 17.0 & 7.5 \\
\hline $\begin{array}{l}\text { The program is cost effective for } \\
\text { landowners/rural residents }\end{array}$ & 54.5 & 43.4 & 2.0 & 41.2 & 45.1 & 13.7 & 69.8 & 24.5 & 5.7 \\
\hline The program is directly beneficial to me & 54.5 & 41.4 & 4.0 & 37.3 & 51.0 & 11.8 & 60.4 & 24.5 & 15.1 \\
\hline $\begin{array}{l}\text { The program increases my sense of safety and } \\
\text { security }\end{array}$ & 49.5 & 43.4 & 7.1 & 31.4 & 51.0 & 17.6 & 52.8 & 32.1 & 15.1 \\
\hline $\begin{array}{l}\text { The program is delivered efficiently, in a timely } \\
\text { manner }\end{array}$ & 49.5 & 47.5 & 3.0 & 37.3 & 54.9 & 7.8 & 64.2 & 30.2 & 5.7 \\
\hline $\begin{array}{l}\text { The program helped me learn how to use bear } \\
\text { spray }\end{array}$ & 60.6 & 34.3 & 5.1 & $\mathrm{~N} / \mathrm{A}$ & $\mathrm{N} / \mathrm{A}$ & $\mathrm{N} / \mathrm{A}$ & $\mathrm{N} / \mathrm{A}$ & $\mathrm{N} / \mathrm{A}$ & $\mathrm{N} / \mathrm{A}$ \\
\hline $\begin{array}{l}\text { The program increased my confidence in using } \\
\text { bear spray }\end{array}$ & 53.5 & 39.4 & 7.1 & $\mathrm{~N} / \mathrm{A}$ & $\mathrm{N} / \mathrm{A}$ & $\mathrm{N} / \mathrm{A}$ & $\mathrm{N} / \mathrm{A}$ & $\mathrm{N} / \mathrm{A}$ & $\mathrm{N} / \mathrm{A}$ \\
\hline
\end{tabular}

a Sample size for this statement is $n=98$. Percent (\%) agreement is calculated based on the number of respondents for each initiative. 
TABLE 5 | Survey respondents' perceived rate of change in livestock depredation and grain/feed damage or loss from carnivores in southwestern Alberta over the past 5 years (2013 through 2018)

\begin{tabular}{lcccc}
\hline & \multicolumn{4}{c}{ Percent (\%) } \\
\cline { 2 - 5 } & Increasing & Same & Decreasing & Undecidec \\
\hline Livestock Depredation & & & 18.5 & 9.3 \\
Grizzly Bear $(n=54)$ & 53.7 & 18.5 & 15.4 & 17.3 \\
Black Bear $(n=52)$ & 11.5 & 55.8 & 7.5 & 15.1 \\
Wolf $(n=53)$ & 26.4 & 50.9 & 3.8 & 15.4 \\
Cougar $(n=52)$ & 17.3 & 63.5 & & 13.5 \\
Grain/Feed Damage or Loss & & & 28.8 & 34.5 \\
Grizzly Bear $(n=52)$ & 34.6 & 23.1 & 24.5 & \\
Black Bear $(n=52)$ & 13.2 & 37.7 & & \\
\hline
\end{tabular}

Results are expressed as a percentage of those responding. ${ }^{a}$ Wolves and Cougars are carnivores (as opposed to omnivores like bears) and typically do not cause grain/feed damage or loss.

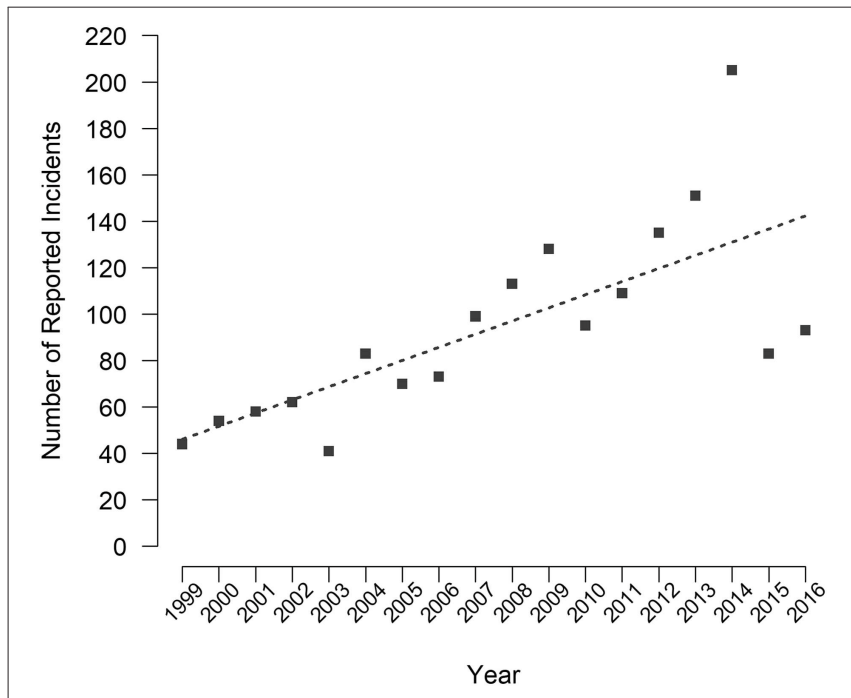

FIGURE 3 | Total combined incidents for grizzly bears, black bears, cougars, and wolves in southwestern Alberta 1999-2016 $\left(y=5.67 x+40.40, R^{2}=\right.$ $0.53, p<0.001)$.

changed from a non-significant increase before the CACP to a significant increase after the implementation of the CACP $(F$ $=9.37, p=0.002$; Pre-CACP $y=0.63 \mathrm{x}+2.73, R^{2}=0.25, p$ $=0.14$; Post-CACP $y=6.44 \mathrm{x}+3.89, R^{2}=0.74, p=0.006$, Figure 6).

\section{Program Costs}

Personnel represented the greatest operating cost to the CACP followed by deadstock removal, attractant management projects, and education and outreach (Table 6). The median total yearly cost of the CACP from 2012-13 to 2018-19 was \$152,968 CAD (Table 6).
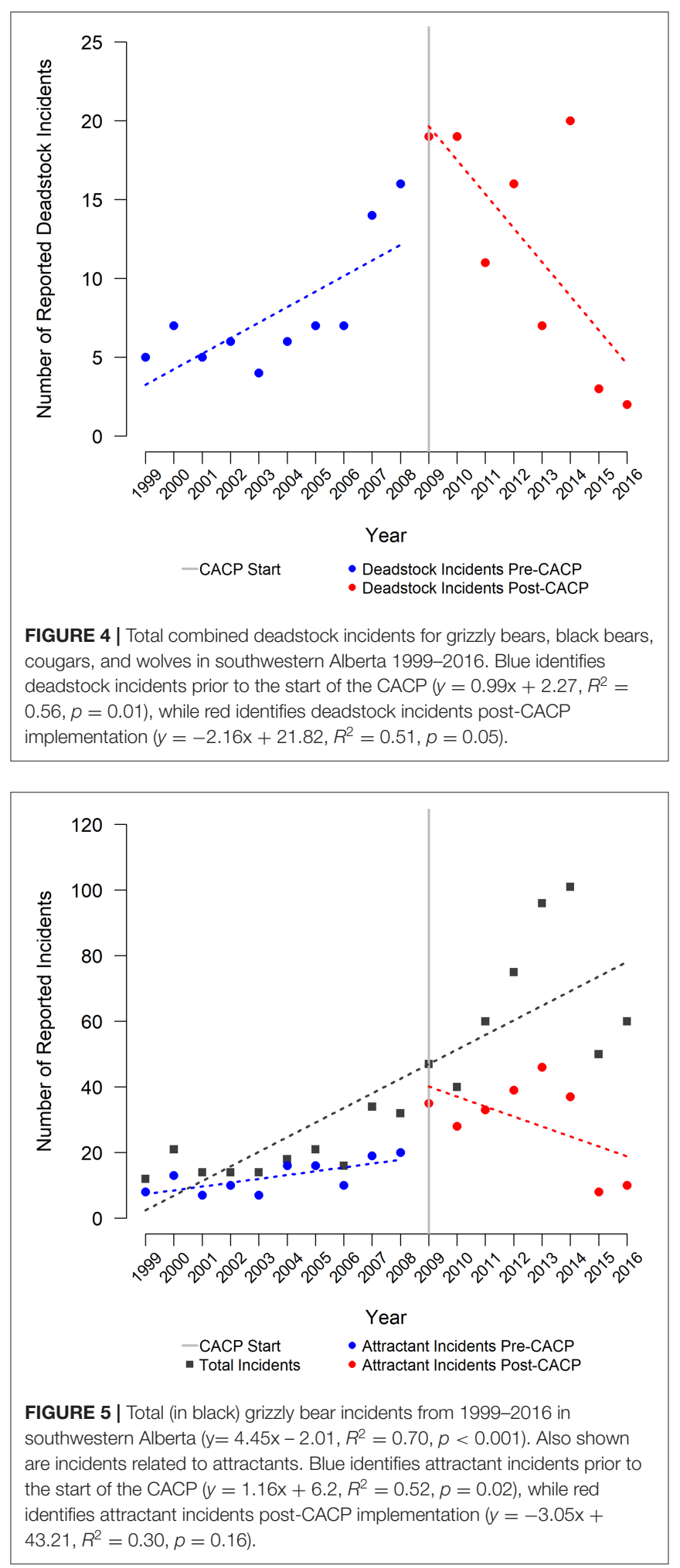

\section{DISCUSSION}

The importance of understanding the first-hand perspectives and experiences of the people who live with large carnivores, who 


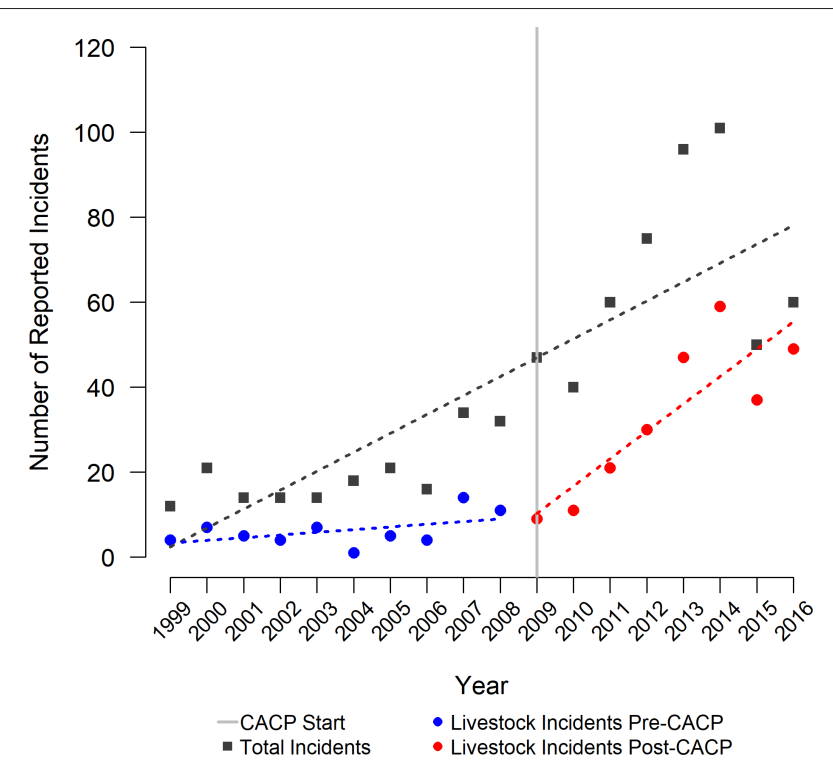

FIGURE 6 | Total (in black) grizzly bear incidents from 1999 to 2016 in southwestern Alberta $\left(y=4.45 x-2.01, R^{2}=0.70, p<0.001\right)$. Also shown are incidents related to livestock depredation or injury. Blue identifies livestock incidents prior to the start of the CACP $\left(y=0.63 x+2.73, R^{2}=0.25, p=\right.$ $0.14)$, while red identifies livestock incidents post-CACP implementation $(y=$ $\left.6.44 \mathrm{x}+3.89, R^{2}=0.74, p=0.006\right)$.

TABLE 6 | Minimum, maximum, and median costs of the Waterton Biosphere Reserve's Carnivores and Communities Program (CACP) from the fiscal years 2012-13 through 2018-19.

\begin{tabular}{lccc}
\hline & \multicolumn{3}{c}{ Yearly Costs CAD $^{\mathrm{a}}$} \\
\cline { 2 - 4 } Program & Minimum & Maximum & Median \\
\hline Deadstock program $^{\mathrm{b}}$ & $\$ 17,000$ & $\$ 75,000$ & $\$ 50,231$ \\
Attractant management $^{\mathrm{c}}$ & $\$ 7,862$ & $\$ 34,209$ & $\$ 21,077$ \\
Education and outreach $^{\mathrm{d}}$ & $\$ 756$ & $\$ 6,495$ & $\$ 4,593$ \\
Personnel & $\$ 62,037$ & $\$ 89,341$ & $\$ 74,228$ \\
Total CACP costs & $\$ 121,077$ & $\$ 185,339$ & $\$ 152,968$ \\
\hline
\end{tabular}

Costs are presented in Canadian dollars (CAD) and are rounded to the nearest whole dollar. Importantly, reported costs do not include in-kind contributions from project partners including landowners, municipal districts, and government agencies.

${ }^{a}$ Fiscal years 2012-13 through 2018-19. In-kind and matching funds are excluded.

$\mathrm{b}$ In 2015, the rendering company removal rate increased from 9 cents/lib. to 14 cents/lb., and the minimum pickup fee increased from $\$ 75$ to $\$ 120$ CAD.

${ }^{c}$ Projects are cost-shared with landowners, most generally on a 50/50 basis. Landowner contribution is excluded.

dIncludes bear safety workshops.

are also often expected to implement policy recommendations, is increasingly recognized as a vital part of conservation programming (Carter and Linnell, 2016; Hughes and Nielsen, 2018). Employing a Theory of Change (ToC) approach enabled us to not only conceptually model the CACP (Figure 1), but also to target our evaluation of the program's effectiveness using data from program participants direct experiences and perspectives, carnivore incident records, and program costs (Allen et al., 2017). The CACP's activities reflect the local context and problems with large carnivores and, as a primary goal, help reduce direct costs and risks to ranchers and rural residents. Using a ToC to guide our evaluation enabled us to conceptualize the impact pathway of each intervention, at the scale of implementation for people in southwestern Alberta (Chen, 2015; Woodhouse et al., 2015). We suggest that other conservation organizations consider using a ToC approach in program development and evaluation, given its flexible and adaptive application as well as utility in engaging a diversity of actors in designing community-based conservation (Center for Theory of Change, 2013; Baylis et al., 2016; Allen et al., 2017).

Indeed, our results indicate the CACP appears to be wellsituated to help meet the needs of the local community. For example, survey respondents identified personal and family safety as a primary concern of living with carnivores. To help address safety issues, the CACP, in consultations with the community, developed a bear safety workshop, which was generally positively received. These workshops not only allow for information exchange and hands-on practice with bear spray, but also bring people together in a collective environment to learn. The workshops espouse principles of building and fostering social capital, including co-learning and knowledge exchange in a safe and respectful environment (Pretty and Smith, 2004). Despite wide acceptance of bear spray efficacy in the scientific community (Smith et al., 2008), many people within the general public do not carry bear spray (Coltrane and Sinnott, 2015; Gunther et al., 2015).

Increasing the use of bear spray as a non-lethal deterrent requires a normative shift in beliefs and behavior, which can be achieved by leveraging influential social bonds across participants (Gockeritz et al., 2009). Within any particular social context, individuals tend to conform to perceived social norms in an effort to be accepted (i.e., normative social influence) and use others as a guide for determining appropriate actions (i.e., informational social influence) (Gockeritz et al., 2009). Research also suggests that individuals retain verbal information better than written information (Gunther et al., 2015), and that messages need to be deemed relevant in order to elicit behavioral change (Miller et al., 2017). Participants of the CACP's bear safety workshop are likely influenced by their social relationships, which in turn can contribute to their adoption of bear safety principles such as carrying bear spray (Pretty and Smith, 2004; Gockeritz et al., 2009). To this end, CACP large carnivore safety workshops are explicitly targeted to farm and ranch families to both improve first-hand knowledge but also to acknowledge that living with large carnivores presents a safety risk, and the messaging within the course speaks to participant values and experiences (Miller et al., 2017; Cinner, 2018). While we did not specifically examine relations of trust, we suggest it is likely that the credentials and relationships of CACP personnel with local participants carry a level of trust and respect that would influence receptivity of the information presented (Pretty and Smith, 2004). This is also referred to as both bonding and linking social capital, where strong community or neighborhood relationships coupled with local groups being involved in decision-making exercises with other agencies can result in bringing people together to address a common problem (Marin et al., 2012). As a result, well over half 
of workshop participants indicated they now carry bear spray, which in turn suggests a shift toward desired normative beliefs and behavior.

In addition to the survey results, our use of incident records allowed us to further explore conflict patterns. Both survey results and incident records indicate incidents related to attractants have declined since CACP implementation. In particular, incident records specify that reported deadstock incidents have declined, and survey respondents expressed that they want the deadstock removal program to continue. The removal of deadstock is important because all four large carnivores scavenge at these sites (Morehouse and Boyce, 2011; Banfield, 2012; Northrup and Boyce, 2012). Certainly, easy access for carnivores to a high-quality food source like deadstock can result in increased species abundance, survival and/or productivity (Sullivan and Sullivan, 1982; Angerbjörn et al., 1991; Morris et al., 2011; Seward et al., 2013), which in turn may result in higher likelihood of human-carnivore encounters, safety risks and potentially exacerbate conflicts. While the practicality of the deadstock removal program is clear, we also believe the social capital built and nurtured through the CACP plays a role in successfully addressing human-carnivore conflict (Pretty and Smith, 2004; Marin et al., 2012; Cinner, 2018; Galvin et al., 2018). This can be seen in the governance of the CACP, along with the sharing of information and experiences of local ranchers and residents participating in the different initiatives. In turn, normative behaviors are encouraged with increasing adoption of CACP activities.

While we cannot definitively link the CACP to the detected decrease in reported attractant and deadstock incidents, we believe it is more likely the combined efforts of the CACP including the relations of trust, reciprocity and exchange that are driving the observed patterns rather than unaccounted reporting (Decker et al., 2015; Galvin et al., 2018). Certainly, part of what appears to have been effective for the CACP is direct engagement with, and understanding of, local peoples' concerns, interests, motivations, and expectations of humancarnivore conflict and coexistence (Galvin et al., 2018). Research elsewhere has demonstrated that community-based programs developed using shared conservation goals and a participatory process can positively impact both wildlife and communities (Wilson et al., 2017; Lute et al., 2018; Störmer et al., 2019). Additionally, engaging local individuals directly in the CACP's governance enables opportunities for building trust and decisionmaking capacity (Pretty and Smith, 2004; Marin et al., 2012). In turn, this helps to establish ownership over the program and foster stewardship toward carnivores (Waylen et al., 2010; Clark, 2011).

Additionally, though our results showed several positive patterns, we acknowledge other program outcomes require further work. For example, while reported grizzly bear-attractant incidents have decreased since the CACP implementation, reported livestock depredation or injury caused by grizzly bears has continued to increase. During community meetings held throughout the development of the deadstock removal program, some people questioned whether restricting access to deadstock might make carnivores more likely to depredate livestock.
However, research from other areas of the world suggests this is not the case and carcass removal remains a recommended strategy for reducing livestock depredation (Shivik, 2004; Lagos and Bárcena, 2015). Although we have not evaluated the reasons behind increased grizzly bear depredation of livestock, we suggest it may be due to a combination of an increased grizzly bear population that has expanded its geographic distribution (Morehouse and Boyce, 2016, 2017), reduced government staff numbers and capacity over a large and dispersed landscape, and the existence of problem bears that are involved in multiple livestock depredation events (e.g., Linnell et al., 1999; Morehouse et al., 2016). However, the most likely explanation is perhaps that unlike stationary attractants, such as grain or deadstock that can be dealt with using electric fencing or carcass removal, livestock are free ranging. Thus, depredation is often more difficult to manage and will continue to be a persistent problem in southwestern Alberta as it is globally (Kolowski and Holekamp, 2006; Morehouse and Boyce, 2011; Li et al., 2015; Morehouse et al., 2018). Addressing livestock depredation requires a multi-pronged approach, interdisciplinary collaboration, cultural sensitivity, robust institutional governance systems, and new ways of doing business (Hughes and Nielsen, 2018; van Eeden et al., 2018).

Although the results of our evaluation are promising, we acknowledge that there are limitations. Smaller sample sizes are often common in non-random, purposive sampling because the emphasis is on exploring specific populations, ideas or phenomena (e.g. case studies) rather than quantity and generalizability to a larger population (Rust et al., 2017). Sample sizes for studies using purposive sampling can vary widely (e.g. Lee et al., 2017; Rust, 2017; Bashari et al., 2018; Redford et al., 2018; Mitchell et al., 2019), and we note that our sample size is within the range of other similar published studies. Criticisms of non-experimental evaluations such as ours include accounting for the effect of potential confounding factors on the achievement of program outcomes, which for our study might include changes in enforcement activity, fluctuations in incident reporting rates, variations in large carnivore populations, lack of actual participation despite signing up, or access to other programming unbeknownst to ourselves (Woodhouse et al., 2015). We also acknowledge that we have not explicitly measured tolerance, and favorable views of the CACP do not necessarily mean the community is more accepting of large carnivores. Our survey targeted individuals that were familiar with the CACP. There is likely a section of the community that is not engaged in coexistence efforts and future work to further understand the perspectives of those individuals is warranted.

Further, we recognize incident records are not without error. We have no way of accounting for unreported incident occurrences, and several survey respondents indicated they do not report safety concerns or damage to stored grain or feed when those events occur. Thus, incident records likely underrepresent the extent of carnivore activity in the area. Changes in reporting rates can influence patterns in complaint data, and removal of problem bears by Fish and Wildlife Officers might contribute to changes in incident levels (Howe et al., 2010). Also, the implementation of the CACP itself might have contributed to 
changes in reporting rates with community members perhaps more likely to report incidents as awareness of carnivore-conflict issues increased. Further, changes in natural food availability can influence incident levels for bears, with human-bear conflicts often, but not always (Hertel et al., 2019) increasing in years of poor natural food availability (Baruch-Mordo et al., 2014; Lewis et al., 2014). Changes in human population and demographics might also influence patterns in the occurrence records, but Morehouse and Boyce (2017) reviewed these possibilities and eliminated these as the main reason for increasing carnivore incidents in southwestern Alberta. Additionally, the grizzly bear population in southwestern Alberta has increased since the CACP's implementation (Morehouse and Boyce, 2016), which might also affect the number of incident records (though we acknowledge that an increased bear population does not necessarily mean increased incidents). Data on population trends for the other large carnivore species are not available, but an increase or decrease in populations might also affect reporting rates.

Finally, an additional and important consideration is the financial commitment required to support programs such as the CACP. Indeed, the costs of the CACP are not insignificant and range from $\sim \$ 121,000$ to $\$ 185,300$ CAD per year, though the cost of the program varies from year to year depending on the specific initiatives undertaken. The program operates on grant funding, and securing long-term financial commitment is a continuing challenge. Funding for personnel to implement the program is particularly difficult to find because many granting agencies prefer to fund specific short-term projects as opposed to ongoing personnel costs. Additionally, in-kind contributions from local governments as well as individual landowners are a critical component to program success and help emphasize the necessity of partnerships. We note that the CACP is a cost-share program and many individuals within our program area accept some loss and risk associated with living with large carnivores (WBR, unpublished data). For example, the attractant management projects are typically implemented on a 50/50 costshare basis between the CACP and the individual landowner. It is also not unusual for the landowner to take on $>50 \%$ of the project cost (Loosen et al., 2014; Waterton Biosphere Reserve, 2016). Thus, the costs of the CACP would be far greater if the program had to cover $100 \%$ of all conflict mitigation efforts. The CACP continues to explore options such as livestock carcass composting to help reduce costs of the deadstock program. By helping to offset the costs associated with sharing the landscape with large carnivores, the CACP encourages producers to participate in large carnivore conservation. Persistent conflict between large carnivores and people means that ongoing financial assistance and social and human capital will be required to support longterm coexistence.

\section{CONCLUSIONS}

The CACP works toward supporting coexistence of humans and large carnivores by mitigating and addressing conflicts. Ultimately, it is the ranchers and rural residents who are choosing to participate in the CACP, thereby demonstrating their willingness to participate in non-lethal solutions to coexist with large carnivores. Thus, the program represents a local solution to a global problem. Reconciling the differences among people, and their values for carnivore conservation, is an ongoing conservation challenge (Redpath et al., 2013; Hughes and Nielsen, 2018; Lute et al., 2018; Vucetich et al., 2018). That said, our grassroots and collaboratively designed program acknowledges, supports, and addresses the needs and concerns of people, and we suggest this is demonstrated by our evaluation results. Evaluations of small, community-based conservation projects (e.g., CACP; the Blackfoot Challenge in Montana, USA, https://blackfootchallenge.org/; the Global Snow Leopard and Ecosystem Protection Program in Asia, https://www.globalsnowleopard.org/) framed around the specific context in which they occur, are well-situated to make local policy recommendations based on evidence from participants' perspectives and experiences (Woodhouse et al., 2015; Salerno et al., 2016). These evaluations can also provide valuable insight to other human-wildlife conservation programs at a broader scale in terms of program design (i.e., what worked/failed) and lessons learned (e.g., importance of pre-implementation baseline social and conflict data). Furthermore, our results highlight the importance of involving the local community in planning and decision-making to ensure that the strategies and actions support conservation objectives and resonate with the people expected to implement them. Doing so can also build the social capital to manage carnivore species. To that end, southwestern Alberta landowners have been involved in all stages of the CACP, from program development and evaluation, to the writing of this manuscript.

Our study's insights are useful for both the development of other community-based organizations as well as other evaluation efforts. To be effective, future program evaluations should consider utilizing a participatory ToC approach to prioritize program activities and goals, collect baseline data prior to program implementation, incorporate multiple data sets, and where possible and ethical, use an experimental or quasi-experimental evaluative design (Biggs et al., 2016; Treves et al., 2016; Allen et al., 2017). As the human population increases and wildlife habitat decreases, it is likely that human-carnivore conflicts will remain a persistent conservation challenge. Long-term coexistence of people and large carnivores requires an ongoing multidisciplinary commitment to think creatively, test new ideas, and work collaboratively.

\section{DATA AVAILABILITY STATEMENT}

The datasets generated for this study will not be made publicly available. Two data sets were used in our study: social survey data and carnivore complaint data. For the social survey data, given confidentiality, ethics consent, and agreements made with the community we are not able to share raw individual data. We can share the survey design and questions on request. For the complaint data, these data belong to the government of Alberta 
and we were given permission to use the data in our analysis. We are not, however, allowed to share these provincial data publicly.

\section{ETHICS STATEMENT}

Ethical review and approval was not required for the study on human participants in accordance with the local legislation and institutional requirements. The patients/participants provided their written informed consent to participate in this study.

\section{AUTHOR CONTRIBUTIONS}

$\mathrm{AM}, \mathrm{CH}, \mathrm{NM}, \mathrm{JB}$, and TB conceived the ideas and designed the methodology. AM and $\mathrm{CH}$ analyzed the data and wrote the first draft of the manuscript. All authors contributed to subsequent drafts of the manuscript and gave final approval for publication.

\section{FUNDING}

Funding for this research came from Alberta Conservation Association, Alberta Environment and Parks, Animal

\section{REFERENCES}

Alberta Environment and Parks (2016). Alberta Grizzly Bear (Ursus arctos) Draft Recovery Plan. Alberta Environment and Parks, Alberta Species at Risk Recovery Plan No. 38. Edmonton, AB.

Alberta Government (1991). Management Plan for Wolves in Alberta. Wildlife Management Planning Series Number 4. Forestry, Lands and Wildlife, Fish and Wildlife Division. Edmonton, AB.

Alberta Government (2012). Management Plan for Cougars in Alberta. Wildlife Management Planning Series Number 8. Alberta Environment and Sustainable Resource Development. Wildlife Management Branch. Edmonton, AB.

Alberta Government (2016). Management Plan for Black Bears in Alberta. ISBN: 9781460119297. Wildlife Management Planning. Alberta Environment and Parks, Wildlife Management Branch. Edmonton, AB.

Alberta Government (2019). Alberta Guide to Hunting Regulations. Alberta Government, Edmonton, AB.

Allen, W., Cruz, J., and Warburton, B. (2017). How decision support systems can benefit from a Theory of Change approach. Environ. Manage. 59, 965-965. doi: 10.1007/s00267-017-0839-y

Anand, S., and Radhakrishna, S. (2017). Investigating trends in human-wildlife conflict: is conflict escalation real or imagined. J. Asia Pac. Biodivers. 10, 154-161. doi: 10.1016/j.japb.2017.02.003

Angerbjörn, A., Arvidson, B., Norén, E., and Strömgren, L. (1991). The effect of winter food on reproduction in the arctic fox, Alopex lagopus. J. Anim. Ecol. 60, 705-714. doi: 10.2307/5307

Apps, C. D., McLellan, B. N., and Woods, J. G. (2006). Landscape partitioning and spatial inferences of competition between black and grizzly bears. Ecography 29, 561-572. doi: 10.1111/j.0906-7590.2006.04564.x

Archer, T. M. (2003). Web-Based Surveys. Journal of Extension. Available online at: https://www.joe.org/joe/2003august/tt6.php

Balfour, D. C., Barichievy, C., and Brett, R. (2019). A theory of change to grow numbers of African rhino at a conservation site. Conserv. Sci. Pract. 1:e40 doi: $10.1111 / \operatorname{csp} 2.40$

Banfield, J. E. (2012). Cougar response to roads and predatory behaviour in southwestern Alberta (M.Sc. thesis). University of Alberta, Edmonton, $\mathrm{AB}$, Canada.

Barratt, M. S., and Lenton, S. (2010). Beyond recruitment? Participatory online research with people who use drugs. Int. J. Internet Res. Ethics 3, 69-86.
Welfare Institute (Christine Stevens Wildlife Award), Kenneth M. Molson Foundation, and Nature Conservancy of Canada.

\section{ACKNOWLEDGMENTS}

We thank the Alberta Government for providing access to the occurrence database for southwestern Alberta. We also thank the Waterton Biosphere Reserve's Carnivore Working Group for providing critical feedback on earlier drafts of the social survey and assisting with survey distribution. A. Loosen, T. Malish, S. Rettler, and M. Urmson reviewed occurrence records and we are thankful for their contribution. Finally, we thank P. Frame and A. Loosen for thoughtful comments on earlier versions of this manuscript.

\section{SUPPLEMENTARY MATERIAL}

The Supplementary Material for this article can be found online at: https://www.frontiersin.org/articles/10.3389/fevo. 2020.00002/full\#supplementary-material
Baruch-Mordo, S., Wilson, K. R., Lewis, D. L., Broderick, J., Mao, J. S., and Breck, S. W. (2014). Stochasticity in natural forage production affects use of urban areas by black bears: implications to management of human-bear conflicts. PLoS ONE 9:e85122. doi: 10.1371/journal.pone.0085122

Bashari, M., Sills, E., Peterson, M. N., and Cubbage, F. (2018). Hunting in Afganistan: variation in motivations across species. Oryx 52:526-536. doi: 10.1017/S0030605316001174

Bassing, S. B., Ausband, D. E., Mitchell, M. S., Lukacs, P., Keever, A., Hale, G., et al. (2019). Stable pack abundance and distribution in a harvested wolf population. J. Wildlife Manage. 83, 577-590. doi: 10.1002/jwmg.21616

Baylis, K., Honey-Rosés, J., Börner, J., Corbera, E., Ezzine-de-Blas, D., Ferraro, P. J., et al. (2016). Maintstreaming impact evaluation in nature conservation. Conserv. Lett. 9, 58-64. doi: 10.1111/conl.12180

Biggs, D., Cooney, R., Roe, D., Dublin, H. T., Allan, J. R., Challender, D. W., et al. (2016). Developing a theory of change for a community-based response to illegal wildlife trade. Conserv. Biol. 31, 5-12. doi: 10.1111/cobi.12796

Bjerke, T., and Kaltenborn, B. P. (1999). The relationships of ecocentric and anthropocentric motives to attitudes toward large carnivores. Journal of Environmental Psychology 19, 415-421. doi: 10.1006/jevp.1999.0135

Blanchard, B. M., and Knight, R. R. (1995). Biological consequences of relocating grizzly bears in the Yellowstone Ecosystem. J. Wildlife Manage. 59, 560-565. doi: $10.2307 / 3802463$

Bruskotter, J. T., Nelson, M. P., and Vucetich, J. A. (2015). Hunted predators: intrinsic value. Science 349, 1294-1295. doi: 10.1126/science.349.6254.1294-b

Carter, N. H., and Linnell, J. D. (2016). Co-adaptation is key to coexisting with large carnivores. Trends Ecol. Evol. 31, 575-578. doi: 10.1016/j.tree.2016.05.006

Center for Theory of Change (2013). What Is a Theory of Change? Center for Theory of Change. Available online at: <www.theoryofchange.org/what-istheory-of-change/> (accessed January 31, 2019).

Chapron, G., Kaczensky, P., Linnell, J. D., von Arx, M., Huber, D., Andrén, H., et al. (2014). Recovery of large carnivores in Europe's modern human-dominated landscapes. Science 346, 1517-1519. doi: 10.1126/science.1257553

Chen, H. T. (2015). Practical Program Evaluation: Theory-Driven Evaluation and the Integrated Evaluation Perspective, 2nd Edn. Thousand Oaks, CA: Sage.

Chow, G. C. (1960). Tests of equality between sets of coefficients in two linear regressions. Econometrica 28, 591-605. doi: 10.2307/1910133

Cinner, J. (2018). How behavioral science can help conservation. Science 362, 889-890. doi: 10.1126/science.aau6028 
Clark, S. G. (2011). The Policy Process: A Practical Guide for Natural Resource Professionals. New Haven, CT: Yale University Press.

Coltrane, J. A., and Sinnott, R. (2015). Brown bear and human recreational use of trails in Anchorage, Alaska. Hum Wildlife Interact. 9, 132-147. doi: $10.26077 /$ wzyf-zz97

Decker, D., Smith, C., Forstchen, A., Hare, D., Pomeranz, E., Doyle-Capitman, C., et al. (2015). Governance principles for wildlife conservation in the $21^{\text {st }}$ Century. Conserv. Lett. 9, 290-295. doi: 10.1111/conl.12211

Decker, D. J., and Chase, L. C. (1997). Human dimensions of living with wildlife: a management challenge for the $21^{\text {st }}$ century. Wildlife Soc. Bull. 25, 788-795.

Dickman, A. J., Macdonald, E. A., and Macdonald, D. W. (2011). A review of financial instruments to pay for predator conservation and encourage human-carnivore coexistence. Proc. Natl. Acad. Sci. U.S.A. 34, 13937-13944. doi: $10.1073 /$ pnas. 1012972108

Dillman, D. A., Smyth, J. D., and Christian, L. M. (2009). Mail and Internet Surveys: The Tailored Design Method, 3rd Edn. New York, NY: John Wiley and Sons.

Dorresteijn, I., Milcu, A. I., Leventon, J., Hanspach, J., and Fischer, J. (2016). Social factors mediating human-carnivore coexistence: understanding thematic strands influencing coexistence in Central Romania. Ambio 45, 490-500. doi: 10.1007/s13280-015-0760-7

Eklund, A., López-Bao, J. V., Tourani, M., Chapron, G., and Frank, J. (2018). Limited evidence on the effectiveness of interventions to reduce livestock predation by large carnivores. Sci. Rep. 7:2097. doi: 10.1038/s41598-017-02323-w

Ericsson, G., Bostedt, G., and Kindberg, J. (2008). Wolves as a symbol of people's willingness to pay for large carnivore conservation. Soc. Nat. Resour. 21, 294-309. doi: 10.1080/08941920701861266

Ericsson, G., Heberlein, T. A., Karlsson, J., Bjärvall, A., and Lundvall, A. (2004). Support for hunting as a means of wolf Canius lupus population control in Sweden. Wildlife Biol. 10, 269-276. doi: 10.2981/wlb.2004.032

Espinosa, S., and Jacobson, S. K. (2012). Human-wildlife conflict and environmental education: evaluating a community program to protect the Andean bear in Ecuador. J. Environ. Educ. 43, 55-65. doi: 10.1080/00958964.2011.579642

Galvin, K. A., Beeton, T. A., and Luizza, M. W. (2018). African community-based conservation: a systematic review of social and ecological outcomes. Ecol. Soc. 23:39. doi: 10.5751/ES-10217-230339

Gockeritz, S., Schultz, P. W., Rendon, T., Cialdini, R. B., Goldstein, N. J., and Griskevicius, V. (2009). Descriptive normative beliefs and conservation behavior: the moderating roles of personal involvement and injunctive normative beliefs. Eur. J. Soc. Psychol. 40,514-523. doi: 10.1002/ejsp.643

Government of Alberta (2017). Alberta Wild Species General Status Listing - 2015. Available online at: https://open.alberta.ca/dataset/ad0cb45c-a885-4b5e-947952969f220663/resource/763740c0-122e-467b-a0f5-a04724a9ecb9/download/ sar-2015wildspeciesgeneralstatuslist-mar2017.pdf (accessed November 18, 2019).

Gunther, K. A., Haroldson, M. A., Frey, K., Cain, S. L., Copeland, J., and Schwartz, C. C. (2004). Grizzly bear-human conflicts in the Greater Yellowstone ecosystem, 1992-2000. Ursus 15, 10-22. doi: 10.2192/15376176(2004)015<0010:GBCITG >2.0.CO;2

Gunther, K. A., Reinsertson, E. G., Wyman, T., Bergum, D., Bowersock, N. R., Barblett, A. M., Johnston, E., and Nicholson, J. (2015). Visitor compliance with bear spray and hiking group size in Yellowstone National Park. Yellowstone Sci. $23,41-43$.

Harrison, H., Birks, M., Franklin, R., and Mills, J. (2017). Case study research: foundations and methodological orientations. Forum Qual. Soc. Res. 18, 1-17. doi: 10.17169/fqs-18.1.2655

Hertel, A. G., Zedrosser, A., Kindberg, J., Langvall, O., and Swenson, J. E. (2019). Fluctuating mast production does not drive Scandinavian brown bear behaviour. J. Wildlife Manage. 83, 657-668. doi: 10.1002/jwmg. 21619

Hoare, R. (2012). Lessons from 15 years of human-elephant conflict mitigation: management considerations involving biological, physical and governance issues in Africa. Pachyderm 51, 60-74.

Holmern, T., Nyahongo, J., and Røskaft, E. (2007). Livestock loss caused by predators outside the Serengeti National Park, Tanzania. Biol. Conserv. 135, 518-526. doi: 10.1016/j.biocon.2006.10.049
Hopkins, J. B. III., Herrero, S., Shideler, R. T., Gunther, K. A., Schwartz, C. C., and Kalinowski, S. T. (2010). A proposed lexicon of terms and concepts for human-bear management in North America. Ursus 21, 154-168. doi: 10.2192/URSUS-D-10-00005.1

Howe, E. J., Obbard, M. E., Black, R., and Wall, L. L. (2010). Do public complaints reflect trends in human-bear conflict? Ursus 21, 131-142. doi: 10.2192/09GR013.1

Hughes, C., and Nielsen, S. E. (2018). 'Bear are only the lightning rod': ongoing acrimony in Alberta's grizzly bear recovery. Soc. Nat. Resour. 32, 4-52. doi: $10.1080 / 08941920.2018 .1502853$

Inskip, C., and Zimmermann, A. (2009). Human-felid conflict: a review of patterns and priorities worldwide. Oryx 43, 18-34. doi: 10.1017/S003060530899030X

Johnson, H. E., Lewis, D. L., Lischka, S. A., and Breck, S. W. (2018). Assessing ecological and social outcomes of a bear-proofing experiment. J. Wildlife Manage. 82, 1102-1114. doi: 10.1002/jwmg.21472

Kaczensky, P. (1999). Large carnivore depredation on livestock in Europe. Ursus $11,59-72$.

Karlsson, J., and Sjöström, M. (2007). Human attitudes towards wolves, a matter of distance. Biol. Conserv. 137, 610-616. doi: 10.1016/j.biocon.2007.03.023

Kellert, S. R. (1980). American attitudes toward and knowledge of animals: an update. Int. J. Study of Anim. Problems 1, 87-119.

Kellert, S. R., Black, M., Rush, C. R., and Bath, A. J. (1996). Human culture and large carnivore conservation in North America. Conserv. Biol. 10, 977-990. doi: 10.1046/j.1523-1739.1996.10040977.x

Knopff, A. A., Knopff, K. H., and St, Clair, C. C. (2016). Tolerance for cougars diminished by high perception of risk. Ecol. Soc. 21:33 doi: 10.5751/ES-08933-210433

Kolowski, J. M., and Holekamp, K. E. (2006). Spatial, temporal, and physical characteristics of livestock depredations by large carnivores along a Kenyan reserve border. Biol. Conserv. 128, 529-541. doi: 10.1016/j.biocon.2005.10.021

Lagos, L., and Bárcena, F. (2015). EU sanitary regulation on livestock disposal: implications for the diet of wolves. Environ. Manage. 56, 890-902. doi: 10.1007/s00267-015-0571-4

Lee, T., Good, K., Jamieson, W., Quinn, M., and Krishnamurthy, A. (2017). Cattle and carnivore coexistence in Alberta: the role of compensation programs. Rangelands 39, 10-16. doi: 10.1016/j.rala.2016.11.002

Lewis, D. L., Breck, S. W., Wilson, K. R., and Webb, C. T. (2014). Modeling black bear population dynamics in a human-dominated stochastic environment. Ecol. Model. 294, 51-58. doi: 10.1016/j.ecolmodel.2014. 08.021

Li, C., Jiang, Z., Li, C., Tang, S., Li, F., Luo, Z., et al. (2015). Livestock depredations and attitudes of local pastoralists toward carnivores in the Qinghai Lake Region, China. Wildlife Biol. 21, 204-212. doi: 10.2981/wlb.00083

Linnell, J. D. C., Aanes, R., Swenson, J. E., Odden, J., and Smith, M. E. (1997). Translocation of carnivores as a method for managing problem animals: a review. Biodivers. Conserv. 6, 1245-1257. doi: 10.1023/B:BIOC.0000034011.05412.cd

Linnell, J. D. C., Odden, J., Smith, M. E., Aanes, R., and Swenson, J. E. (1999). Large carnivores that kill livestock: do "problem individuals" really exist? Wildlife Soc. Bull. 27, 698-705.

Loosen, A., Manners, N., and Morehouse, A. (2014). Large Carnivore Attractant Management Projects in Southwestern Alberta 2008-2012. Waterton Biosphere Reserve.

Loosen, A. E., Morehouse, A. T., and Boyce, M. S. (2018). Land tenure shapes black bear density and abundance on a multi-use landscape. Ecol. Evol. 9, 73-89. doi: $10.1002 /$ ece 3.4617

Lute, M. L., Carter, N. H., López-Bao, J., and Linnell, J. D. C. (2018). Conservation professionals agree on challenges to coexisting with large carnivores but not on solutions. Biol. Conserv. 218, 223-232. doi: 10.1016/j.biocon.2017.12.035

Macdonald, E. A., Hinks, A., Weiss, D. J., Dickman, A., Burnham, D., Sandom, C. J., et al. (2017). Identifying ambassador species for conservation marketing. Glob. Ecol. Conserv. 12, 204-214. doi: 10.1016/j.gecco.2017.11.006

Malish, T., and Loosen, A. (2017a). Large Carnivore Occurrences in Southwestern Alberta: 2015 Annual Report. Report prepared for Waterton Biosphere Reserve Association. Available online at: https://www.watertonbiosphere.com/wpcontent/uploads/2017/11/2015-Carnivore-Occurrence-Summary-Mar2017. pdf (accessed July 24, 2019). 
Malish, T., and Loosen, A. (2017b). Large Carnivore Occurrences in Southwestern Alberta: 2016 Annual Report. Report prepared for Waterton Biosphere Reserve Association. Available online at: https://www.watertonbiosphere.com/wpcontent/uploads/2017/06/2016-Carnivore-Occurrence-Summary-FINAL.pdf (accessed July 24, 2019).

Margoluis, R., Stem, C., Salafsky, N., and Brown, M. (2009). Using conceptual models as a planning evaluation tool in conservation. Eval. Program Plann. 32, 138-147. doi: 10.1016/j.evalprogplan.2008.09.007

Marin, A., Gelcich, S., Castilla, J. C., and Berkes, F. (2012). Exploring social capital in Chile's coastal benthic comanagement system using a network approach. Ecol. Soc. 17:13. doi: 10.5751/ES-04562-170113

McKinnon, M. C., Mascia, M. B., Yang, W., Turner, W. R., and Bonham, C. (2015). Impact evaluation to communicate and improve conservation non-governmental organization performance: the case of Conservation International. Philos. Trans. R. Soc. B 370:20140282. doi: $10.1098 /$ rstb.2014.0282

Mech, L. D. (2017). Where can wolves live and how can we live with them? Biol. Conserv. 210, 310-317. doi: 10.1016/j.biocon.2017.04.029

Miller, J. R., Jhala, Y. V., Jena, J., and Schmitz, O. J. (2015). Landscape-scale accessibility of livestock to tigers: implications of spatial grain for modeling predation risk to mitigate human-carnivore conflict. Ecol. Evol. 5, 1354-1367. doi: $10.1002 /$ ece3.1440

Miller, J. R., Jhala, Y. V., and Schmitz, O. J. (2016). Human perceptions mirror realities of carnivore attack risk for livestock: implications for mitigating human-carnivore conflict. PLoS ONE 11:e0162685. doi: 10.1371 /journal.pone. 0162685

Miller, Z. D., Freimund, W., Metcalf, E. C., and Nickerson, N. (2017). Targeting your audience: wildlife value orientations and the relavance of messages about bear safety. Human Dimens, Wildlife. 23, 213-226. doi: 10.1080/10871209.2017.1409371

Milligan, S., Brown, L., Hobson, D., Frame, P., and Stenhouse, G. (2018). Factors affecting the success of grizzly bear translocations. J. Wildlife Manage. 83, 519-530. doi: 10.1002/jwmg.21410

Mitchell, A. M., Bruyere, B., Otieno, T. O., Bhalla, S., and Teel, T. L. (2019). A comparison between human-carnivore conflicts and local community attitudes toward carnivores in Westgate Community Conservancy, Samburu, Kenya. Human Dimens. Wildlife 24, 168-179. doi: 10.1080/10871209.2018.1548671

Morehouse, A. T., and Boyce, M. S. (2011). From venison to beef: seasonal changes in wolf diet composition in a livestock grazing landscape. Front. Ecol. Environ. 9, 440-445. doi: 10.1890/100172

Morehouse, A. T., and Boyce, M. S. (2016). Grizzly bears without borders: spatially explicity capture-recapture in southwestern Alberta. J. Wildlife Manage. 80, 1152-1166. doi: 10.1002/jwmg.21104

Morehouse, A. T., and Boyce, M. S. (2017). Troublemaking carnivores: conflicts with humans in a diverse assemblage of large carnivores. Ecol. Soc. 22:4. doi: 10.5751/ES-09415-220304

Morehouse, A. T., Graves, T. A., Mikle, N., and Boyce, M. S. (2016). Nature vs. nurture: evidence for social learning of conflict behaviour in grizzly bears. PLoS ONE 11:e0165425. doi: 10.1371/journal.pone.0165425

Morehouse, A. T., Tigner, J., and Boyce, M. S. (2018). Coexistence with large carnivores supported by a predator-compensation program. Environ. Manage. 61, 719-731. doi: 10.1007/s00267-017-0994-1

Morris, G., Hostetler, J. A., Oli, M. K., and Conner, L. M. (2011). Effects of predation, fire, and supplemental feeding on populations of two species of Peromyscus mice. J. Mammal. 92, 934-944. doi: 10.1644/10-MAMM-A-419.1

Musiani, M., Mamo, C., Boitani, L., Callaghan, C., Gates, C. C., Mattei, L., et al. (2003). Wolf depredation trends and the use of fladry in western North America. Conserv. Biol. 17, 1538-1547. doi: 10.1111/j.1523-1739.2003.00063.x

Naughton-Treves, L., Grossberg, R., and Treves, A. (2003). Rural citizens' attitudes toward wolf depredation and compensation. Conserv. Biol. 17, 1500-1511. doi: 10.1111/j.1523-1739.2003.00060.x

Newsome, T. M., Dellinger, J. A., Pavey, C. R., Ripple, W. J., Shores, C. R., Wirsing, A. J., et al. (2015). The ecological effects of providing resource subsidies to predators. Global Ecol. Biogeogr. 24, 1-11. doi: 10.1111/geb.12236

Northrup, J. M., and Boyce, M. S. (2012). Mad cow policy and management of grizzly bear incidents. Wildlife Soc. Bull. 36, 499-505. doi: 10.1002/wsb.167

Nyhus, P. J. (2016). Human-wildlife conflict and coexistence. Annu. Rev. Environ. Resour. 41, 18.1-18.29. doi: 10.1146/annurev-environ-110615-085634
Palinkas, L. A., Horwitz, S. M., Green, C. A., Wisdon, J. P., Duan, N., and Hoagwood, K. (2015). Purposeful sampling for qualitative data collection and analysis in mixed method implementation research. Admin. Policy Mental Health 42, 533-544. doi: 10.1007/s10488-013-0528-y

Pérez, E., and Pacheco, L. F. (2006). Damage by large mammals to subsistence crops within a protected area in a montane forest of Bolivia. Crop Protect. 25, 933-939. doi: 10.1016/j.cropro.2005.12.005

Peterson, M. N., Birckhead, J. L., Leong, K., Peterson, M. J., and Peterson, T. R. (2010). Rearticulating the myth of human-wildlife conflict. Conserv. Lett. 3, 74-82. doi: 10.1111/j.1755-263X.2010.00099.x

Pretty, J., and Smith, D. (2004). Social capital in biodiversity conservation and management. Conserv. Biol. 18, 631-638. doi: 10.1111/j.1523-1739. 2004.00126.x

Proctor, M. F., Kasworm, W. F., Annis, K. M., Machutchom, A. G., Teisberg, J. E., Radandt, T. G., et al. (2018). Conservation of threatened Canada-USA trans-border grizzly bears linked to comprehensive conflict reduction. Human Wildlife Interact. 12, 348-372. doi: 10.26077/yjy6-0m57

Ratnayeke, S., Van Manen, F. T., Pieris, R., and Pragash, V. S., J. (2014). Challenges of large carnivore conservation: sloth bear attacks in Sri Lanka. Hum. Ecol. 42, 467-479. doi: 10.1007/s10745-014-9643-y

Redford, K. H., Hulvey, K. B., Williamson, M., and Schwartz, M. W. (2018). Assesment of the conservation measures partnership's effort to improve conservation outcomes through adaptive management. Conserv. Biol. 32, 926-937. doi: 10.1111/cobi.13077

Redpath, S. M., Young, J., Evely, A., Adams, W. M., Sutherland, W. J., Whitehouse, A., et al. (2013). Understanding and managing conservation conflicts. Trends Ecol. Evol. 28, 100-109. doi: 10.1016/j.tree.2012.08.021

Riley, S. J., and Decker, D. J. (2000). Wildlife stakeholder acceptance capactiy for cougars in Montana. Wildlife Soc. Bull. 28, 931-939.

Ripple, W. J., Estes, J. A., Beschta, R. L., Wilmers, C. C., Ritchie, E. G., Hebblewhite, M., et al. (2014). Status and ecological effects of the world's largest carnivores. Science 343:1241484. doi: 10.1126/science. 1241484

Rust, N. A. (2017). Can stakeholders agree on how to reduce humancarnivore conflict on Namibian livestock farms? A novel Q-methodology and Delphi exercise. Oryx 51, 339-346. doi: 10.1017/S00306053150 01179

Rust, N. A., Abrams, A., Challender, D. W. S., Chapron, G., Ghoddousi, A., Glikman, J. A., et al. (2017). Quantity does not mean quality: the importance of qualitative social science in conservation research. Soc. Nat. Resour. 29, 1079-1094. doi: 10.1080/08941920.2017.1333661

Salerno, J., Mulder, M. B., Grote, M. N., Ghiselli, M., and Packer, C. (2016). Household livelihoods and conflict with wildlife in communitybased conservation areas across northern Tanzania. Oryx 50, 702-712. doi: $10.1017 /$ S0030605315000393

Sato, Y. (2017). The future of urban brown bear management in Sapporo, Hokkaido, Japan: a review. Mammal Study 42, 17-30. doi: 10.3106/041.042.0102

Seward, A. M., Beale, C. M., Gilbert, L., Jones, T. H., and Thomas, R. J. (2013). The impact of increased food availability on survival of a long-distance migratory bird. Ecology 94, 221-230. doi: 10.1890/12-0121.1

Shivik, J. A. (2004). Non-lethal alternatives for predation management. Sheep Goat Res. J. 19, 64-71.

Shivik, J. A. (2006). Tools for the edge: what's new for conserving carnivores. Bioscience 56, 253-259. doi: 10.1641/0006-3568(2006)056[0253:TFTEWN]2.0. $\mathrm{CO} ; 2$

Smith, T. S., Herrero, S., Debruyn, T. D., and Wilder, J. M. (2008). Efficacy of bear deterrent spray in Alaska. J. Wildlife Manage. 72, 640-645. doi: $10.2193 / 2006-452$

Statistics Canada (2016). Census Profile, 2016 Census: Pincher Creek No. 9, Municipal District, Alberta. Statistics Canada, Ottawa, ON. Available online at: http://www12.statcan.gc.ca/census-recensement/2016/dp-pd/prof/details/ page.. $\mathrm{cm}$ ? Lang $=\mathrm{E} \& \mathrm{Geo} 1=\mathrm{CSD} \&$ Code $1=4803011 \& \mathrm{Geo} 2=\mathrm{CD} \& \mathrm{Code} 2=4803 \&$ $\mathrm{Data}=$ Count\&SearchText=pincher\%20 creek\&SearchType=Begins\&SearchPR= 01\&B1=All\&TABID=1 (Accessed January 31, 2019).

Störmer, N., Weaver, L. C., Stuart-Hill, G., Diggle, R. W., and Naidoo, R. (2019). Investigating the effects of community-based conservation on attitudes towards wildlife in Namibia. Biol. Conserv. 233, 193-200. doi: 10.1016/j.biocon.2019.02.033 
Sullivan, T. P., and Sullivan, D. S. (1982). Population dynamics and regulation of the Douglas squirrel (Tamiasciurus douglasil) with supplemental food. Oceologia 53, 264-270. doi: 10.1007/BF00545675

Treves, A. (2009). Hunting for large carnivore conservation. J. Appl. Ecol. 46, 1350-1356. doi: 10.1111/j.1365-2664.2009.01729.x

Treves, A., Krofel, M., and McManus, J. (2016). Predator control should not be a shot in the dark. Front. Ecol. Environ. 14, 380-388. doi: 10.1002/fee.1312

Treves, A., and Naughton-Treves, L. (1999). Risk and opportunity for humans coexisting with large carnivores. J. Hum. Evol. 36, 275-282. doi: 10.1006/jhev.1998.0268

van Eeden, L. M., Crowther, M. S., Dickman, C. R., Macdonald, D. W., Ripple, W. J., Ritchie, E. G., et al. (2018). Managing conflict between large carnivores and livestock. Conserv. Biol. 32, 26-34. doi: 10.1111/cobi.12959

Vucetich, J. A., Bruskotter, J. T., and Nelson, M. P. (2015). Evaluative whether nature's intrinsic value is an axiom of or anathema to conservation. Conserv. Biol. 29, 321-332. doi: 10.1111/cobi.12464

Vucetich, J. A., Burnham, D., Macdonald, E. A., Bruskotter, J. T., Marchini, S., Zimmermann, A., et al. (2018). Just conservation: what is it and should we pursue it? Biol. Conserv. 221, 23-33. doi: 10.1016/j.biocon.2018.02.022

Wang, S. W., and Macdonal, D. W. (2006). Livestock predation by carnivores in Jigme Singye Wangchuck National Park, Bhutan. Biol. Conserv. 129, 558-565. doi: 10.1016/j.biocon.2005.11.024

Washington, H., Baillie, J., Waterman, C., and Milner-Gulland, E. J. (2015). A framework for evaluating the effectiveness of conservation attention at the species level. Oryx 49, 481-491. doi: 10.1017/S0030605314000763

Waterton Biosphere Reserve (2016). Large Carnivore Attractant Management Projects in Southwetsern Alberta 2013-2014. Waterton Biosphere Reserve.

Waylen, K. A., Fischer, A., McGowan, P. J., Thirgood, S. J., and MilnerGulland, E. J. (2010). Effect of local cultural context on the success of community-based conservation internventions. Conserv. Biol. 24, 1119-1129. doi: $10.1111 / j .1523-1739.2010 .01446 . x$
Wilson, S. M., Bradley, E. H., and Neudecker, G. A. (2017). Learning to live with wolves: community-based conservation in the Blackfoot Valley of Montana. Human Wildlife Interact. 11, 245-257. doi: 10.26077/bf8e-6f56

Wilson, S. M., Madel, M. J., Mattson, D. J., Graham, J. M., and Merrill, T. (2006). Landscape conditions predisposing grizzly bears to conflicts on private agricultural lands in the western USA. Biol. Conserv. 130, 47-59. doi: 10.1016/j.biocon.2005.12.001

Woodhouse, E., Homewood, K. M., Beauchamp, E., Clements, T., McCabe, J. T., Wilkie, D., et al. (2015). Guiding principles for evaluating the impacts of conservation interventions on human well-being. Philos. Trans. R. Soc. B 370:20150103. doi: 10.1098/rstb.2015.0103

Young, J. K., Ma, Z., Laudati, A., and Berger, J. (2015). Human-carnivore interactions: lessons learned from communities in the American West. Hum. Dimens. Wildlife 20, 349-366. doi: 10.1080/10871209.2015.1016388

Zorrilla-Pujana, J., and Rossi, S. (2016). Environmental education indicators system for protected areas management. Ecol. Indic. 67, 166-155. doi: 10.1016/j.ecolind.2016.02.053

Conflict of Interest: AM is self-employed by Winisk Research and Consulting.

All authors declare that the research was conducted in the absence of any commercial or financial relationships that could be construed as a potential conflict of interest.

Copyright (®) 2020 Morehouse, Hughes, Manners, Bectell and Bruder. This is an open-access article distributed under the terms of the Creative Commons Attribution License (CC BY). The use, distribution or reproduction in other forums is permitted, provided the original author(s) and the copyright owner(s) are credited and that the original publication in this journal is cited, in accordance with accepted academic practice. No use, distribution or reproduction is permitted which does not comply with these terms. 